\title{
Geographic variation of Barbus radiatus Peters, a widely distributed African cyprinid fish
}

\author{
Donald J. Stewart \\ School of Natural Resources and Museum of Zoology, The University of Michigan, \\ Ann Arbor, Michigan, USA
}

\section{Keywords :}

Africa, Barbus, Cyprinidae, Ecotypic, Fish, Geographic variation, Phenetics, Principal components, Systematics

\section{Synopsis}

Barbus radiatus is a widely distributed, polytypic species with three recognized subspecies: radiatus Peters (1853), aurantiacus Boulenger (1910), and profundus Greenwood (1970). A phenetic analysis of relative similarity was conducted for specimens of $B$. radiatus from throughout its known range. The study focuses on several large population samples taken recently along the presumed central Zambian interface between the subspecies aurantiacus and radiatus. New data on meristic and morphometric variation in $B$. radiatus and recent rediscovery of typical radiatus in Lake Victoria demonstrate that profundus is a species distinct from radiatus. With respect to the remaining two subspecies, results indicate a populational mosaic of highly variable morphs rather than two discrete, allopatric morphs. Thus, aurantiacus is placed in synonymy of radiatus. It is hypothesized that the populational mosaic of morphology in radiatus reflects adaptive ecotypic responses to water temperature and current velocity. The characters which accounted for most of the geographic variation of radiatus were body depth, caudal peduncle length, longitudinal meristic counts, dorsal fin height, and orbit diameter.

\section{Introduction}

This study is a contribution to understanding morphological variation in populations of Barbus

Received 3.5.1976 Accepted 18.11.1976 radiatus, a widely distributed, polytypic species with three recognized subspecies: radiatus Peters (1853), aurantiacus Boulenger (1910), and profundus Greenwood (1970). The typical subspecies is distributed from the Aswa River in Uganda, southward to the Pongolo River in Natal, and westward to central Zambia where it interfaces with the western subspecies aurantiacus (Fig. 1). B. $r$. profundus is endemic to the deep waters of Lake Victoria.

It is proposed herein to accord full specific rank to profundus because this taxon has several characteristics which transcend variation in radiatus. Rationale for the change and a contrast of the two species are deferred to the systematic revision section. The following analysis of morphological variation will be confined to the two forms of radiatus.

$B$. $r$. radiatus generally has orbit diameter less than interorbital width, whereas, aurantiacus has orbit diameter greater than interorbital width. This is the only character that has proven to be diagnostic and, together with a presumed allopatric distribution, precludes synonymy of the two taxa. When the above criterion was used to classify $B$. radiatus from several recent collections made in Zambia, it became apparent that zoogeography of the two radiatus morphs was more complex than previously envisioned. A population referable to aurantiacus was found isolated in the Luongo River above Musonde Falls (Fig. 2 and 3); typical radiatus occurred just below the falls. This and other distributional anomalies as well as specimens difficult to refer to either morph suggested the need for further study. 


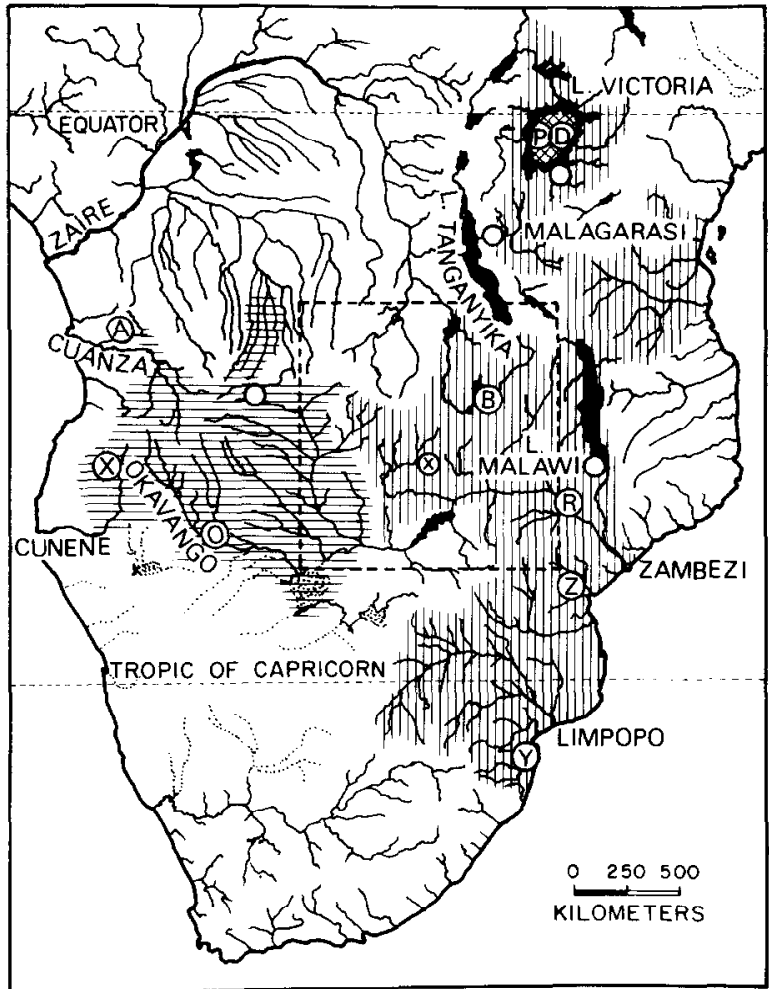

Fig. 1. Distribution in Africa of B. r. radiatus (vertical), aurantiacus (horizontal), and profundus (crossed) (after Greenwood 1970 and Bailey 1969). Circled letters indicate type localities: $\mathrm{R}=$ radiatus, synonyms are doggetti (D), bangwelensis $(\mathrm{B})$, palustris $(\mathrm{Z})$, and rubellus $(\mathrm{Y}) . \mathrm{A}=$ aurantiacus, synonyms are rogersi $(\mathrm{X})$, and okavangoensis $(\mathrm{O}) . \mathrm{P}=$ profundus. The boxed area is enlarged in Fig. 3. Open circles indicate populations outside the boxed area that were studied herein.

There seems to be no agreement on which form of $B$. radiatus occurs in the Kafue, Bangweulu, or Upper Zambezi systems (Bell-Cross 1965, 1968, 1972; Greenwood 1963, 1970; Jubb 1967, 1968; Ladiges 1964). Taken together, the differing opinions of these authors support the observation that many populations of $B$. radiatus are difficult to categorize and may cast doubt on the validity of recognizing two subspecies. It was my objective to examine morphological variation of $B$. radiatus and thereby to reevaluate the need of recognizing two subspecies.

\section{Methods and materials}

This study encompasses material from 22 localities from throughout the known range of $B$. radiatus with an emphasis on the central Zambian interface

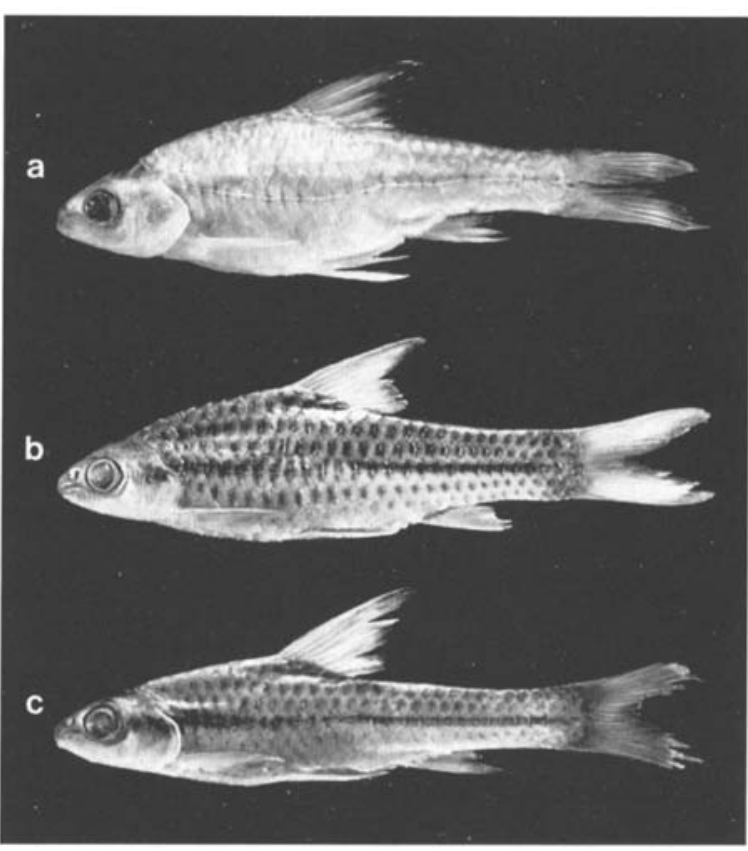

Fig. 2. (a) Barbus profundus paratype, $52 \mathrm{~mm}$, Lake Victoria (BMNH 1970.5.14:2-4); (b) B. radialus, $67 \mathrm{~mm}$, Lower Luongo River, Zambia (ROM 28075); (c) B. radiatus, $78 \mathrm{~mm}$, Upper Luongo River, Zambia (ROM 28049), slender morph resembling aurantiacus.

between the two subspecies (Fig. 1 and 3). For the following list of material examined, lots marked with an asterisk were not used in the principal components analysis. Size of specimens is given in standard length. Abbreviations for institutions are as follows: Albany Museum, Grahamstown (AMPF); British Museum (Natural History), London (BMNH); Natal Museum, Pietermaritzburg (NPB); Royal Ontario Museum, Toronto (ROM); Tervuren Museum, Tervuren (TM); and University of Michigan Museum of Zoology, Ann Arbor (UMMZ).

East of Zambia: Types. - BMNH 1904.5.19:24 Barbus doggetti holotype, $82 \mathrm{~mm}$, Lake Victoria, W. Doggett; BMNH 1938.5.6:1-8 Beirabarbus palustris paratypes, (14)26-53 mm, swampy savannah $12 \mathrm{~km}$ from Beira, Moçambique, A. Herre, 30-IV-1936; BMNH 1960.11.5:1-2 and BMNH 1960.11.5:3-5 Barbus rubellus paratypes, *(5), Mzenyeni Pan, Ingwavuma District, Zululand, R. Crass, 17-IX-1956. Nontypes. - UMMZ 194962, $67 \mathrm{~mm}$, Lake Victoria, depth $2 \mathrm{~m}$ in open water adjacent to dense Vossia, Mwanza, Tanzania, worm on hook and line, D. Stewart and R. Scully, 


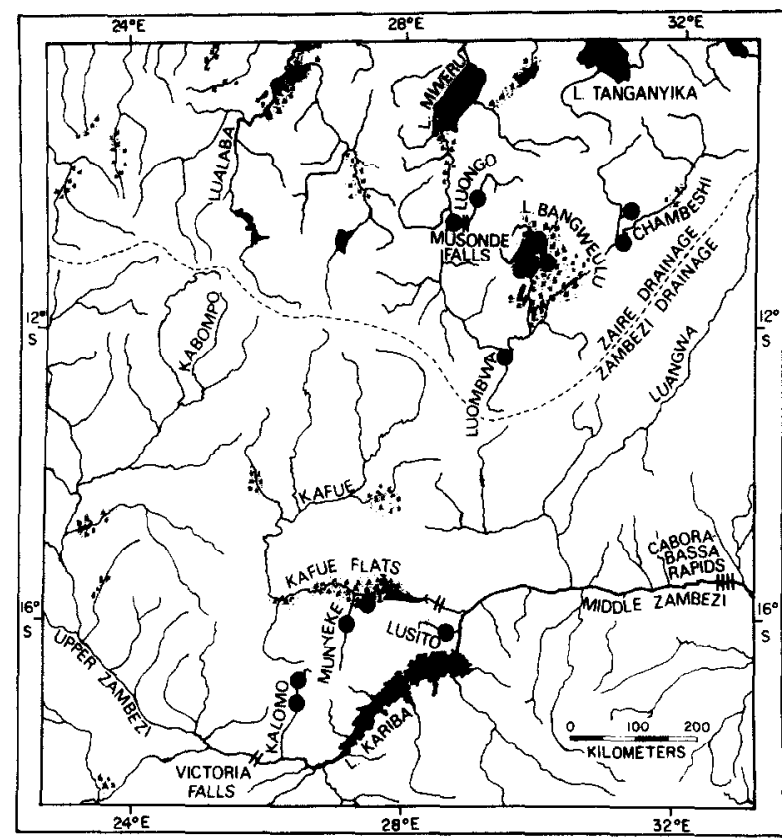

Fig. 3. Zambian localities (•) for B. radiatus material used herein.

23-X-1973; UMMZ 198865, *74 mm, seasonal tributary of Lake Victoria, $32 \mathrm{~km} \mathbf{E}$ of Mwanza, Tanzania, R. Scully, 12-IV-1974; BMNH 1971.6. $22: 135-136,{ }^{*}(2) 70-89 \mathrm{~mm}$, Malagarasi River, Uvinga, Tanzania, P. Greenwood, R. LoweMcConnell and G. Lockley, 18-IX-1952; BMNH 1932.11.15:343-360, *(meas. 10 of 20) $38-77 \mathrm{~mm}$, Lake Malawi, Bar House and Deep Bay, Malawi, Christy; AMPF 1922, *(2) 40-46 mm, Mzenyeni Pan, Ingwavuma District, Zululand, R. Crass, 17-IX-1956; AMPF 1266, * (2) 38-41, Malambogwenya River, Jozini, Pongolo River drainage, (R. Pott in mid-1960's?).

In Zambia: Types - BMNH 1905.11.10:6 Barbus bangwelensis holotype, $76 \mathrm{~mm}$, Lake Bangweulu, F. Melland; BMNH 1910.1.26:5 Barbus rogersi paralectotype, ${ }^{*} 44 \mathrm{~mm}$, Umsitu River, Kafue-Zambezi drainage, near Broken Hill (= Kabwe), Rogers. Nontypes. - ROM 28049, (meas. 25 of 174)30-117 mm, Upper Luongo River (above Musonde Falls), $16 \mathrm{~km} \mathrm{~W}$ of Mwenda, 0.5-4 m deep, 18-20 m wide, slow current, turbid water, macrophytes and some rocks, in deep grassy ravine, rotenone, E. Balon, 17-XI-1970; ROM 28075, (meas. 25 of 36) 56-89 mm, Lower Luongo River ( $15 \mathrm{~km}$ below Musonde Falls), near ferry crossing, 0.2-1 m deep, 25-35 m wide, fast current, rocky outcrops with gravel, sand and mud, in hillocks valley, rotenone, E. Balon, 18-XI-1970; BMNH 1943.7.27:221-230, (meas. 11 of 13) 45$57 \mathrm{~mm}$, Bangweulu Swamps, Chilui Island, Matipa, purchased, C. Ricardo and R. Owen, 4 to 20-XII1936; BMNH 1932.12.16:124-143, (meas. 6 of 20)28-32 mm, Luombwa River, C. Pitman, 16-XII-1932; UMMZ 198863, (meas. 25 of 75) 28-53 mm, Chambeshi River at Kasama-Mpika highway, near shore, depth to $1 \mathrm{~m}$, moderate current, clear water, sand and silt with macrophytes along shore, rotenone, R. M. Bailey and D. Stewart, 4-XI-1970; UMMZ 198862, (2)58$62 \mathrm{~mm}$, tributary to Chambeshi River at road $53 \mathrm{~km}$ S of Kasama, swampy stream $0.5-4 \mathrm{~m}$ wide, $0.3 \mathrm{~m}$ deep, slow current, clear water, sand and gravel, Typhus and sedges, rotenone, R. M. Bailey and D. Stewart, 4-XI-1970; UMMZ 198864, (25) 26-71 mm, Kafue Flats in Lochinvar National Park near Chunga, depth to $2 \mathrm{~m}$, turbid water, muddy substrate, abundant macrophytes, rotenone and seine, J. Kapetsky and D. Stewart, 3 to 15-II1970; UMMZ 198861, 46 mm, Munyeke Stream at Monze-Namwala road $41 \mathrm{~km} \mathrm{~W}$ of Lochinvar turnoff, seasonal tributary of Kafue Flats, dry to pools $1-8 \mathrm{~m}$ wide, $0.5 \mathrm{~m}$ deep, sand, gravel and rocks, rotenone and seine, R. M. Bailey and D. Stewart, 21-X-1970; ROM uncat., (meas. 25 of 51) 36$53 \mathrm{~mm}$, Kalomo River $12 \mathrm{~km}$ downstream from Kalomo township, braided stream averaging $3.5 \mathrm{~m}$ wide, $0.5 \mathrm{~m}$ deep, rapids and sand, also a pool with reeds, toxicant and seine, E. Balon, 29-IV-1969; ROM uncat., (meas. 11 of 13) $80-90 \mathrm{~mm}$, reservoir of Kalomo Dam on Kalomo River $163 \mathrm{~km}$ upstream from confluence with Zambezi River, 250-300 m wide in downstream third and less than $50 \mathrm{~m}$ wide in upstream half, gill net and seine, E. Balon, 5 to 7-II-1970; ROM uncat., $61 \mathrm{~mm}$, Lusito River at Chipangula $26.5 \mathrm{~km}$ from confluence with Zambezi River, alternating rapids and pools at a large bend in the river, $10 \mathrm{~m}$ wide, gravel and large boulders, toxicant and seine, E. Balon, 22-IV-1969.

West of Zambia: Types. - BMNH 1911.6.1:78 Barbus aurantiacus lectotype, $76 \mathrm{~mm}$, and BMNH 1911.6.1: 79-80 paralectotypes, (2) $46-65 \mathrm{~mm}$, Rio Lucalla at Lucalla, Rio Cuanza drainage, Angola, W. Ansorge; BMNH 1949.12.30:1-10 Beirabarbus okavangoensis paratypes, (10)30-54 mm, Okavango River at Runtu, South West Africa, Eedes, 1939; BMNH 1907.6.29:149 Barbus rogersi lectotype, *48 mm, Rio Que, Rio Cunene drainage, Angola, W. Ansorge. Nontypes. - TM 160243-245, ${ }^{*}(3)$ 
64-71 mm, and TM 160246-254, *(9)39-55 mm, Lac Colundo, Upper Zambezi River drainage, Angola, I-1955.

Subsequent reference to various populations is made using name of the river or lake from which the sample was taken. For type localities, name of the associated nominal species is used. The type of doggetti and two recently collected radiatus specimens from Lake Victoria are all referred to as 'doggetti'; also, two specimens from Mzenyeni Pan (type locality of rubellus) and two from the nearby Malambogwenya River are referred to as 'rubellus'.

Large population samples were subsampled to obtain a representative length range for both sexes and a total of up to 25 complete specimens. For samples of less than 25 , all specimens from which a complete set of data could be taken were used. Data were taken for eleven morphometric characters with needle-point calipers to the nearest $0.1 \mathrm{~mm}$ and six meristic characters whenever possible (Table 1).

The fleshy orbital rim was difficult to measure accurately, especially in old material. Diameter of the orbit was measured as the horizontal distance from the posterior rim of the lachrymal (or the lateral ethmoid when it projected out) to the

Table 1. Morphometric and meristic characters of $B$. radiatus that were examined; one through ten were used in the principal components analysis.

1. Standard length, tip of snout to caudal base

2. Body depth, greatest dimension, usually at dorsal origin.

3. Caudal peduncle depth, least dimension.

4. Caudal peduncle length, posterior end of anal base to a vertical through caudal base.

5. Predorsal length, snout to dorsal fin origin.

6. Height of last unbranched dorsal ray, from structural base.

7. Head length, snout to tip of membranous opercular margin.

8. Snout length, tip to anterior bony orbital rim.

9. Interorbital width, least distance across frontals, measured medial to supraorbitals.

10. Diameter of orbit, bony margin from lachrymal or lateral ethmoid to rim of posterior suborbital.

11. Posterior barbel length.

12. Lateral line scales, pored scales to caudal base, excluding pored scales on caudal fin.

13. Predorsal scales, dorsal origin to occiput along midlinc.

14. Circumference scale count, rows around body just ahead of dorsal origin.

15. Circumpeduncular scalc rows, around narrowest part of caudal peduncle.

16. Principal dorsal fin rays.

17. Postweberian vertebrae, excluding the urocentrum. anterior rim of the suborbital behind the eye. The bony interorbital width was taken as least distance across the frontals (excluding the supraorbitals). This method gave values consistently lower than those reported by other authors but fulfilled the necessary criterion of being repeatable with a minimum of error for specimens of all sizes and all states of preservation.

A phenetic analysis of similarity among ten morphometric characters (Table 1) of 182 individual specimens from 16 populations was conducted using principal components analysis. Components were extracted from the correlation matrix of character vectors standardized to zero means and unit standard deviations. Methods are those used by Smith (1973) except that unscaled Eigenvectors were used herein. The components are defined by variates corresponding to the principal axes of the observations in multivariate space; the $\mathrm{i}^{\text {th }}$ principal component is that linear compound of characters which explains the $i^{\text {th }}$ largest portion of the total character variance (Morrison 1967).

Principal components analysis is used here to summarize variation in morphology of $B$. radiatus and to identify characters with the greatest relative contribution to variation. A plot of projection scores for individuals against the first two principal components (Fig. 4) provides a convenient graphic display of relative similarity of specimens from various populations. Each specimen is considered a separate operational taxonomic unit and judgments about phenetic relationships are made according to which specimens cluster together in the multivariate hyperspace.

\section{Results}

\section{Meristics}

Nearly every specimen had nine principal dorsal fin rays. The unbranched first ray was followed by eight (rarely nine) branched rays, the last of which was always split to the base. Circumference scale counts were also nearly invariate. Every specimen had 12 circumpeduncular scale rows and all but a few had 16 scale rows around the body just ahead of the dorsal fin origin. The typical pattern was three rows between the mid-dorsal row and lateral line plus three between the lateral line and midventral row. Six of 14 palustris paratypes and the smaller aurantiacus paralectotype had the mid- 
Table 2 Frequency distributions of vertebrae and lateral line scale counts for $B$. radiatus from various localities. Lake Nabugabo data is from Greenwood (1963, lateral line; 1970, vertebrae).

\begin{tabular}{|c|c|c|c|c|c|c|c|c|c|c|c|c|}
\hline \multirow{2}{*}{ Locality } & \multicolumn{5}{|c|}{ Vertebrae } & \multicolumn{7}{|c|}{ Lateral line scales } \\
\hline & 26 & 27 & 28 & 29 & 30 & 24 & 25 & 26 & 27 & 28 & 29 & 30 \\
\hline Upper Luongo River & & & & 25 & & & 1 & 2 & 15 & 6 & 1 & \\
\hline Ten Zambian localities & 1 & 12 & 110 & 7 & 1 & 9 & 52 & 43 & 4 & & & \\
\hline B. palustris, paratypes & 1 & 8 & 1 & & & 4 & 2 & 3 & & & & \\
\hline Lake Nabugabo, Uganda & & & 9 & 5 & & & & 3 & 5 & 4 & 1 & 1 \\
\hline
\end{tabular}

ventral row partially doubled to give possible counts of 17 rows.

Longitudinal meristic counts reveal some interesting variation (Table 2); the pattern for vertebrae closely parallels that for lateral line scales indicating a redundancy in these characters. It appears that specimens from the Upper Luongo have a mode of one myomere more than most other radiatus. $B$. palustris have a mode of one myomere less. Most of the variation in vertebrae counts seems to be due to addition or reduction of caudal vertebrae; there were typically 14 precaudal vertebrae. Specimens with less than 28 vertebrae often had two neural spines on the penultimate centrum. The single specimen from Munyeke Stream had 30 vertebrae. The Upper Luongo population had nine or ten predorsal scales compared to eight or nine for most other radiatus.

\section{Phenetic similarities}

Correlations between morphometric characters and the first two principal components indicate that the first component is simply related to size of the specimens ( $r=0.97$ to 1.00 for all characters). The second principal component is of greatest interest because effects due to size have been removed and the complex of characters with highest correlations are precisely those upon which the subspecies radiatus and aurantiacus were predicated. The second component is positively correlated with depth characteristics $(r=0.19,0.22)$ and negatively correlated with each of the very different characters dorsal fin height $(r=-0.17)$, caudal peduncle length $(r=-0.13)$, and orbit diameter $(r--0.15)$. The first two components together account for 98.8 percent of the variation in the multivariate system. The Eigenvalue is 9.72 for the first component and 0.157 for the second.
The third and fourth components were extracted but were not significant.

The plot of projection scores for individuals on the first two principal components (Fig. 4) can be viewed as having size increasing from left to right on the horizontal axis. Diagonal trends in the plot reflect changes in morphology with growth. The vertical axis expresses the dichotomy between a radiatus-like morph at the top and an aurantiacuslike morph at the bottom. Correspondence between morphometric trends along the vertical axis and meristic trends (Table 2) is excellent. The $B$. palustris and Upper Luongo populations represent extremes in more or less equal and opposite directions. Specimens clustered to the top of the plot are deep-bodied with small eyes, low dorsal fin, and short caudal peduncle. The reverse is true of those to the bottom.

Differences between types considered synonyms of radiatus (i.e., doggetti, bangwelensis) and aurantiacus are bridged by variation in material from Zambia. Projection of the type specimens on the second component alone reveals the east-west cline which was part of the rationale for recognizing two subspecies. The holotype of bangwelensis is intermediate in form and historically it has been one of the more difficult to classify.

\section{Morphometric proportions}

The principal components analysis provided a general overview of the relative similarity of various populations and identified characters with the greatest relative contribution to variation. When these characters are expressed as percentage of standard length (SL) and analyzed individually (Fig. 5), the sources of variation along the second principal component are revealed in greater detail. The basis for positive and negative character cor- 


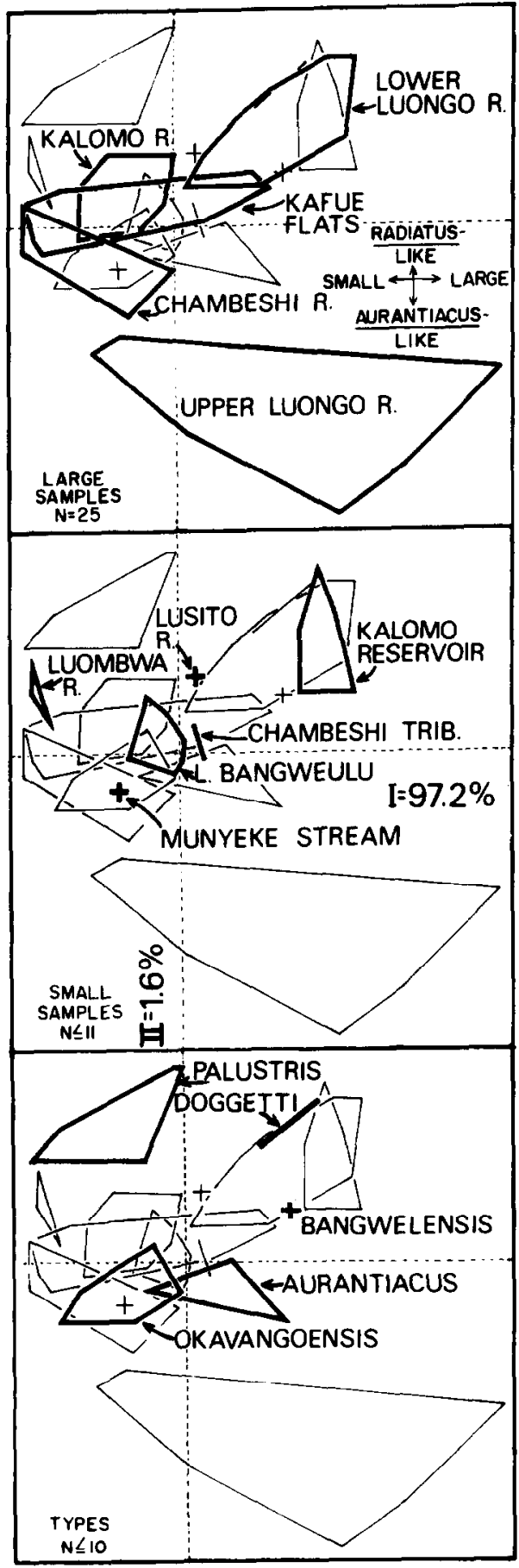

Fig. 4. Relative similarity of $B$. radiatus from selected populations as indicated by projection scores of individuals on the first two principal components. The cluster of points representing each population was circumscribed and individual points omitted. Different populations are successively highlighted in three views of the same plot. relations with component two can be easily seèn in comparison of trends for body depth and dorsal fin height. The pattern for orbit diameter and interorbital width is remarkably similar to that for dorsal height. Interorbital width did not emerge as important in the principal components analysis but is included here because of its prior use as a diagnostic character. The pattern for caudal peduncle length also follows that for dorsal fin height in the eastern and Zaire drainage populations but is less consistent for the other localities. An important result with respect to the systematics of radiatus is the observation that a spectrum of population morphs occurs in each of the regions studied. Data on the lectotype of $B$. radiatus (Fig. 5 ) indicate that it would cluster near okavangoensis if included in the principal components analysis (Fig. 4). It might also be noted that for any given population, one or more characters may have $95 \%$ confidence limits of the mean non-overlapping with the limits for several other population means.

Body-depth variation was similar to that for caudal peduncle depth indicating a redundancy in these two characters. Variation in depth may be in part a function of the nutritional state or reproductive condition of individuals comprising a population. The Chambeshi River sample included some specimens which appeared emaciated but all other populations appeared to be in good condition. The Kalomo Reservoir sample was all large, gravid females but the sample mean was not significantly different from that of the Kalomo River sample which included much smaller specimens (Fig. 5). Where adequate samples were available, it was consistently observed that males and females had similar mean depth but the females were more variable.

Caudal peduncle length may vary with changes in vertebral number but the correspondence is not as good as might be expected. Mean length of the last caudal centrum was determined from $x$-rays of ten Upper Luongo specimens to be $1.8 \%$ of SL. The range in caudal peduncle length for that sample spans almost four percent of SL but every specimen has 29 vertebrae. Having an extra caudal vertebra might account for only half the difference in mean peduncle length between Upper and Lower Luongo populations. Also, the Munyeke specimen with 30 vertebrae has a relatively short caudal peduncle.

Posterior barbel length was difficult to measure accurately as measurements were typically between 


\begin{tabular}{|c|c|c|c|c|c|c|c|}
\hline \multicolumn{2}{|r|}{ POPULATION } & $\begin{array}{r}n: S . L \\
(m m)\end{array}$ & $\begin{array}{l}\text { CHARACTEF } \\
\text { Body Depth } \\
22242628303234\end{array}$ & $\begin{array}{l}\text { R AS PERCENTA } \\
\begin{array}{|llll}\text { Dorsal Fin Height } \\
22 \quad 24 & 26 \quad 28 & 30 & 32\end{array}\end{array}$ & $\begin{array}{l}\text { GE OF } \\
\text { Orbit } \\
\text { Diameter } \\
8 \quad 1012\end{array}$ & $\begin{array}{l}\text { TANDAF } \\
\text { Inter- } \\
\text { orbital } \\
468\end{array}$ & $\begin{array}{l}\text { RD LENGTH } \\
\text { Caudal } \\
\begin{array}{l}\text { Ceduncle Length } \\
16 \text { 18 20 22 24 } 26\end{array}\end{array}$ \\
\hline$\stackrel{5}{\leftarrow}$ & $\begin{array}{l}\text { B.'doggetti' } \\
\text { Malagarasi R. } \\
\text { L. Malawi } \\
\text { B.radiatus } \\
\text { B.palustris } \\
\text { B.'rubellus' }\end{array}$ & \begin{tabular}{|c|}
$3: 67 \cdot 82$ \\
$2: 70-89$ \\
$10: 38 \cdot 77$ \\
$1: 35$ \\
$14: 26-53$ \\
$4: 38-46$ \\
\end{tabular} & 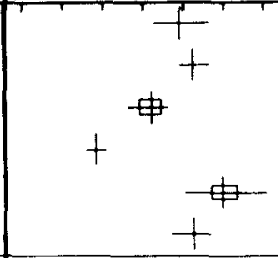 & $\begin{array}{c}+ \\
+ \\
+n=9 \\
+\end{array}$ & $\begin{array}{c}t \\
t \\
+ \\
+ \\
+ \\
+\end{array}$ & $\begin{array}{c}t \\
t \\
\text { N } \\
+ \\
t \\
t\end{array}$ & $\begin{array}{l}+ \\
+ \\
+ \\
+ \\
\text { 中- } n: 10 \\
+\end{array}$ \\
\hline 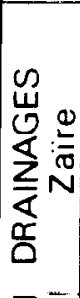 & $\begin{array}{l}\text { B.bangwelensis } \\
\text { L.Bangweulu } \\
\text { Luombwa R. } \\
\text { Chambeshi R. } \\
\text { Chambeshi Trib. } \\
\text { Lower Luongo R. } \\
\text { Upper Luongo R. }\end{array}$ & \begin{tabular}{|c|}
$1: 76$ \\
$11: 45-57$ \\
$6: 28-32$ \\
$25: 28-53$ \\
$2: 58-62$ \\
$25: 56-89$ \\
$25: 30-117$
\end{tabular} & 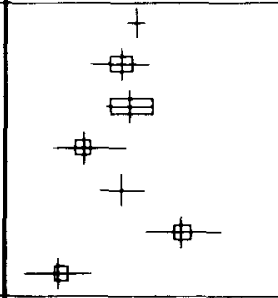 & $\begin{array}{l}+ \\
\text { 申 } \\
\text { 中 } \\
+ \\
+ \text { 中- }\end{array}$ & $\begin{array}{l}+ \\
\phi \\
\text { 由 } \\
+ \\
+ \\
+ \\
+\end{array}$ & $\begin{array}{l}+ \\
+ \\
+ \\
+ \\
t \\
+ \\
+\end{array}$ & $\begin{array}{c}+ \\
+ \\
+\rightarrow \\
+ \\
+ \\
+\phi\end{array}$ \\
\hline 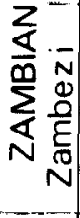 & $\begin{array}{l}\text { Kafue Flats } \\
\text { Munyeke Stream } \\
\text { Kalomo R. } \\
\text { Kalomo Res. } \\
\text { Lusito R. }\end{array}$ & \begin{tabular}{|l|}
$25: 26-71$ \\
$1: 46$ \\
$25: 36-53$ \\
$11: 80-90$ \\
$1: 61$
\end{tabular} & $\begin{array}{l}+ \text { \# } \\
- \text { 申 } \\
+\end{array}$ & $\underbrace{\frac{1}{+}}_{+}$ & $\begin{array}{c}-4 \\
+ \\
+ \\
+\end{array}$ & $\begin{array}{l}+t \\
t \\
t \\
t\end{array}$ & $\begin{array}{l}+ \\
+ \\
+ \\
+ \\
+\end{array}$ \\
\hline 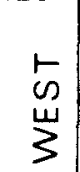 & $\begin{array}{l}\text { B. aurantiacus } \\
\text { B. okavangoensis } \\
\text { B. rogersi } \\
\text { L. Colundo }\end{array}$ & $\begin{array}{r}3: 46-76 \\
10: 30-54 \\
2: 44-48 \\
12: 39-71\end{array}$ & $\begin{array}{l}+ \\
+ \\
+ \\
\text { ND }\end{array}$ & $\begin{array}{c}+ \\
+\mathrm{n} \cdot 1 \\
\mathrm{ND}\end{array}$ & $\begin{array}{l}+ \\
+ \\
+ \\
\text { 中 }\end{array}$ & $\begin{array}{c}t \\
+ \\
+\end{array}$ & $\begin{array}{c}t \\
\text { ND } \\
t\end{array}$ \\
\hline
\end{tabular}

Fig. 5. Variation of selected morphometric characters of B. radiatus. Parameters illustrated are the mean (vertical bar), range (horizontal bar), and $95 \%$ confidence limits for the mean (Blocks). Confidence limits were approximated using a method based on Fieller's Theorem (Goldstein 1964: 184-187); these are often asymmetrical relative to the mean because the method takes into account the compound variance of ratios. Confidence limits for samples less than five are wider than the range of observations and not plotted. Data for the lecotype of $B$. radiatus are from Greenwood (1963). N. D. = no data.

0.5 and $1 \mathrm{~mm}$. Range of observations (as percentage of SL) overlapped broadly for all populations and no useful patterns of variation in barbel length were detected.

\section{Allometry}

Upper and Lower Luongo River populations have divergent trends toward lower and upper corners of the principal components plot (Fig. 4) which may reflect allometric growth of various characters. Slope of the relationship between dorsal fin height (as a percentage of SL) and standard length appeared to differ slightly for the two Luongo River populations; this may contribute to the divergent trends observed. Dorsal fin height as a percentage of SL was found to decrease with increasing size. For each of the two Luongo River samples, small specimens had dorsal fins roughly three percent of SL longer than large fish, but the data were highly variable. This basically agrees with Banister's (1973: Fig. 55) findings for $B$. intermedius and other species of large Barbus; as size increases, they have a negative exponential trend in dorsal spine length as a percentage of SL. Such negative allometry probably contributes to the wide range of dorsal fin height observations for various radiatus populations (Fig. 5) and may partially explain the short fins of the Kalomo Reservoir specimens.

A ratio of orbit diameter and interorbital width has been used to distinguish aurantiacus from radiatus. These same characters are noted for their allometric growth changes in a wide variety of 
fishes. Greenwood (1963:23) noted that the ratio of these characters seems to change with increasing size of aurantiacus but remains nearly constant in radiatus. The same pattern emerges if values for these two characters are plotted versus standard length for the two Luongo populations (Fig. 6). Slopes of the first principal axes fit through each bivariate scatter of points indicate that for the Lower Luongo population, growth rate of both characters relative to standard length is similar (i.e., the axes are nearly parallel). This contrasts with the Upper Luongo population where the two axes diverge with increasing size. Convergence of orbit-size axes for small specimens of the two populations combined with intersection of the interorbital axes points out a possible source of error in using these measurements to diagnose taxa.

If the same analysis is made using the conventional exponential model for allometric growth, fit of the axes through the scatter of points is only slightly improved. The exponential model indicates, however, that orbit and interorbital axes are nearly parallel for the Upper Luongo population

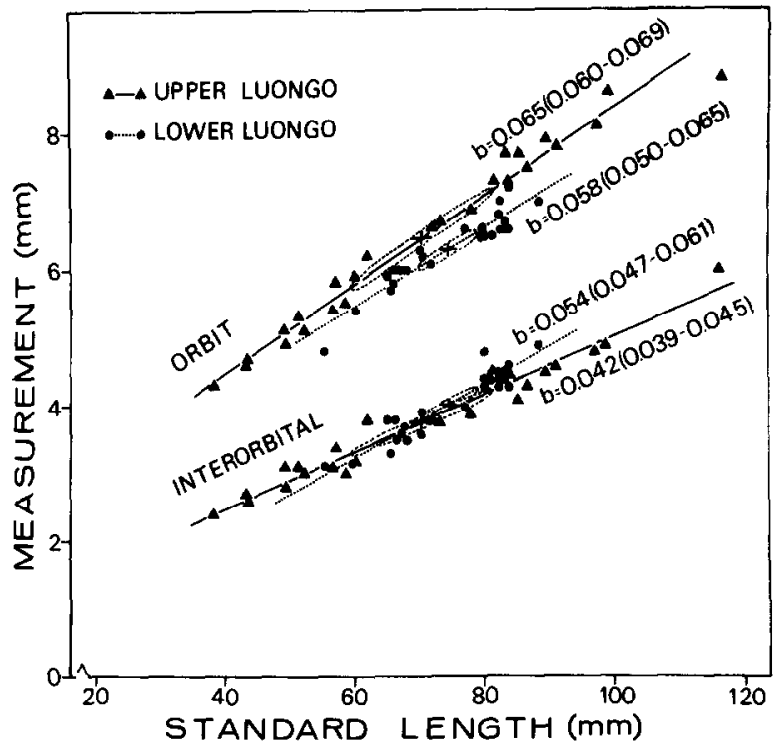

Fig. 6. Change in orbit diameter and interorbital width versus size of radiatus from allopatric populations in the Luongo River as indicated by slope ( $b$ and $95 \%$ confidence limits of $b$ ) of the first principal axis through each bivariate scatter of observations. The $95 \%$ confidence elipse for each bivariate mean $(+)$ is also given. Statistical procedures are from Sokal \& Rholf (1969: 526-532) with one change recommended by Ricker (1973: 415, footnote). and converge with increasing size for the Lower Luongo population. Unfortunately, the lack of very small specimens for each population makes it difficult to resolve the actual growth pattern that gives rise to each morph of radiatus. Apparently, relative growth rates of various body parts during very early life are especially important in moderating the ultimate form of the fish (Barlow 1961).

\section{Systematic revisions}

The results indicate that there are not two discrete allopatric morphs of radiatus. Instead there is a populational mosaic of highly variable morphs. It is thus reasonable to place aurantiacus in the synonymy of radiatus. With the expanded data base now available (see below) it is also apparent that morphology of profundus is well outside the bounds of the most extreme morphs of radiatus discussed above; profundus should be elevated from subspecific rank.

\section{Barbus radiatus Peters}

$$
\text { Fig. 2b,c }
$$

Barbus radiatus Peters 1853:783 (the larger of two syntypes was designated lectotype by Greenwood 1963, the paralectotype was not identified).

Barbus doggetti Boulenger $1904: 450$.

Barbus bangwelensis Boulenger 1905:643-644.

Barbus aurantiactus Boulenger 1910:554 (lectotype designated by Greenwood 1962).

Barbus rogersi Boulenger 1911:180, Fig. 158 (lectotype designated by Greenwood 1962).

Beirabarbus palustris Herre $1936: 100$.

Beirabarbus okavangoensis Barnard 1941:470-471.

Barbus rubellus Crass 1960:431-433, Fig. 1 (paratypes polyspecific, see below).

\section{Diagnosis}

A species of Barbus with well developed sensory pitlines covering the head; it is thus classified in the subgenus Enteromius Cope 1869 (Greenwood 1970). This character alone separates radiatus from all other species of Barbus known from within its distribution range except profundus (Fig. 1). Diagnostic characters for separating radiatus from profundus are presented in Table 3. Among the eleven species now classified in Enteromius (nine in West Africa), radiatus is distinguished for the most part by its short but ever-present posterior barbels which were minute to at most $2.6 \%$ of SL for the specimens which I measured $(n=160)$. Greenwood 
Table 3. Contrasting characteristics of Barbus radiatus and $B$. profundus (based on Greenwood 1970, and most of the material examined herein).

\begin{tabular}{|c|c|c|}
\hline Character & radiatus & profundus \\
\hline Barbels & usually 4 present & absent \\
\hline $\begin{array}{l}\text { Second pharyngeal } \\
\text { tooth of primary } \\
\text { row }\end{array}$ & $\begin{array}{l}\text { always stouter and } \\
\text { taller than other } \\
\text { teeth }\end{array}$ & not enlarged \\
\hline $\begin{array}{l}\text { Circumpeduncular } \\
\text { scale rows }\end{array}$ & always 12 & $\begin{array}{l}\text { mode } 9 \\
8 \text { to } 11\end{array}$ \\
\hline $\begin{array}{l}\text { Circumference } \\
\text { scale rows }\end{array}$ & $16(17)$ & 16 to 18 \\
\hline $\begin{array}{l}\text { Ratio height:length } \\
\text { of exposed surface } \\
\text { on lateral line } \\
\text { scale below dorsal } \\
\text { fin origin }\end{array}$ & $\begin{array}{l}\bar{X}=2.68 \\
2.50 \text { to } 2.78 \\
11 \text { paratypes } \\
\text { of palustris }\end{array}$ & $\begin{array}{l}\bar{X}=3.48 \\
2.67104 .46 \\
n=23\end{array}$ \\
\hline $\begin{array}{l}\text { Postweberian } \\
\text { vertebrae }\end{array}$ & $\begin{array}{l}\text { mode } 28 \\
27 \text { to } 29(30)\end{array}$ & $\begin{array}{l}\text { mode } 30 \\
29 \text { to } 31\end{array}$ \\
\hline $\begin{array}{l}\text { Interparietal } \\
\text { fontanelle }\end{array}$ & $\begin{array}{l}\text { usually closed at } \\
\text { a size of } 30 \mathrm{~mm}\end{array}$ & $\begin{array}{l}\text { often open to a } \\
\text { size of } 40 \mathrm{~mm}\end{array}$ \\
\hline $\begin{array}{l}\text { Habitat in Lake } \\
\text { Victoria }\end{array}$ & $\begin{array}{l}\text { littoral zone and } \\
\text { both ephemeral and } \\
\text { permanent tributaries }\end{array}$ & $\begin{array}{l}\text { deep water only, } \\
18 \text { to } 65 \mathrm{~m}\end{array}$ \\
\hline
\end{tabular}

(1962:197) reports an average of $2.3 \%$ of SL and a maximum of $5.6 \%$. Six of the West African species of Enteromius have barbels. Of these, ablabes (Bleeker) 1863 is perhaps the most similar to radiatus but differs in having longer posterior barbels (5.7 to $8.9 \%$ SL, Hopson and Hopson 1965).

\section{Comments}

Five paratypes of rubellus were examined at the BMNH but were not included in the foregoing analysis because all had been dessicated and the series was polyspecific. One large specimen was referable to radiatus but a second specimen in the same lot (BMNH 1960.11.5:1-2; original NPB numbers missing) and three in another lot (BMNH 1960.11.5:3-5; formerly NPB $150 / 2,4,7$ ) were tenttatively identified as $B$. annectens. The large specimen contrasted noticeably with the others in having sensory pitlines readily visible on the head (absent in the others), much shorter barbels, longer snout, and a different gill raker morphology. The shortest snout which I observed for radiatus was $6.8 \%$ of SL (range 6.8 to $8.8, \mathrm{n}=209$ ) and the long- est barbel observed was $2.6 \%$ of SL. On the basis of these two characters, the holotype and half of the paratypes of rubellus are referable to radiatus (Crass 1960; Table II, NPB 146/1-8) and the remaining paratypes (NPB 150/1-7) are some other species, perhaps annectens. $B$. radiatus typically have three relatively slender, pointed and spaced gill rakers on the lower limb of the anterior arch with two or three pad-like rakers below them. In contrast, annectens (AMPF 1265) and NPB $150 / 2,4,7$ have about eight pad-like, contiguous gill rakers on the lower anterior arch. Dr. R. Jubb was kind enough to reexamine the holotype of rubellus and confirmed that it is radiatus.

\section{Zoogeography}

$B$. radiatus is reported here for the first time from the Lake Tanganyika drainage where it was collected in the Malagarasi River, Tanzania. The species has also been collected near Maun, Botswana, where it is common ( $\mathrm{K}$. Banister, letter of 4 June 1976). It seems likely that future explorations will bring new range extensions.

When profundus was discovered, radiatus was known from Lake Victoria only by the type of doggetti (1904, precise locality unknown). Several years of intensive collecting by personnel of the East African Freshwater Fisheries Research Organization established that radiatus occur in larger, permanent tributaries to the lake but no new specimens were found in the lake proper or its ephemeral tributaries. It was thus suspected that the doggetti type came from a tributary and profundus was thought to be a lacustrine subspecies (Greenwood 1970).

In 1973, I spent a week with Mr. R. Scully who was then with USAID/EAFFRO in Mwanza, Tanzania. Intent on seeing some of the fascinating Lake Victoria cichlids, I baited a small hook with earthworm and began fishing. Much to my surprise, I caught a Barbus radiatus. Subsequently, Mr. Scully has sent me a single gravid female radiatus which he collected in a tributary to Speke Gulf that flows only during the heavy rains of March and April. These new records dispel prior concerns about the apparent absence of typical radiatus in the lake proper and support the arguments given herein for elevating profundus; but obviously, they do not demonstrate sympatry as there remains a $16 \mathrm{~m}$ depth segregation. 


\section{Barbus profundus Greenwood}

Fig. 2a

Barbus radiatus profundus Greenwood 1970:1-13; illustrated pharyngeal teeth only, Fig. 1A.

Holotype: BMNH 1970.5.14:1,59 mm, $2^{\circ} 09^{\prime} 5^{\prime \prime} \mathrm{S}$, $32^{\circ} 35^{\prime} 5^{\prime \prime} \mathrm{E}$, Sta.T267, depth $57 \mathrm{~m}$, mud, Lake Victoria, trawl, P. Greenwood, 27-II-1970. Paratypes. - (All lot numbers are prefixed by BMNH 1970.5.14: : 2-4, (3) 52-57 mm, same data as holotype; 6-8, (3) 38-55 mm, $0^{\circ} 50^{\prime} 0^{\prime \prime} \mathrm{S}, 32^{\circ} 35^{\prime} 0^{\prime \prime} \mathrm{E}$, Sta.U389, 60-61 m, mud; 10-12, (3) $54-57 \mathrm{~mm}$, $0^{\circ} 38^{\prime} 5^{\prime \prime} \mathrm{S}, 32^{\circ} 30^{\prime} 0^{\prime \prime} \mathrm{E}$, Sta.U382, $52 \mathrm{~m}$, mud; 18 , $57 \mathrm{~mm}, 2^{\circ} 12^{\prime} 5^{\prime \prime} \mathrm{S}, 32^{\circ} 45^{\prime} 5^{\prime \prime} \mathrm{E}$, Sta. 237, $50 \mathrm{~m}$, hard mud; $40-42$, (3) $54-58 \mathrm{~mm}, 1^{\circ} 30^{\prime} 0^{\prime \prime} \mathrm{S}, 32^{\circ} 23^{\prime} 5^{\prime \prime} \mathrm{E}$, Sta.T233, 62-64 m, mud; 43, $58 \mathrm{~mm}, 0^{\circ} 02^{\prime} 0^{\prime \prime} \mathrm{S}$, $32^{\circ} 27^{\prime} 0^{\prime \prime} \mathrm{E}$, Sta. $220,59-62 \mathrm{~m}$, mud; 44-46, (3) 54$60 \mathrm{~mm}, 1^{\circ} 12^{\prime} 0^{\prime \prime} \mathrm{S}, 32^{\circ} 22^{\prime} 0^{\prime \prime} \mathrm{E}, \mathrm{Sta} .222,54-57 \mathrm{~m}$, clay; 80-83, (4) 52-63 mm, $0^{\circ} 45^{\prime} 0^{\prime \prime} \mathrm{S}, 32^{\circ} 38^{\prime} 0^{\prime \prime} \mathrm{E}$, Sta.U388, 56-57 m, mud; 97-98, (2) $52-57 \mathrm{~mm}$, $1^{\circ} 32^{\prime} 0^{\prime \prime} \mathrm{S}, 32^{\circ} 17^{\prime} 5^{\prime \prime} \mathrm{E}$, Sta.T271, 56-58 m, clay; (one paratype not seen). All from Lake Victoria, trawl, P. Greenwood, 15 to 28-II-1970.

\section{Diagnosis}

A species of the subgenus Enteromius. No maxillary barbels, a mode of nine ( 8 to 11 ) circumpeduncular scale rows, and other characters (Table 3) readily distinguish profundus from radiatus (the only other Enteromius known from the Lake Victoria basin). In West Africa there are three known species of Enteromius which lack barbels. Of these, aspilus Boulenger 1907 has 12 circumpeduncular scale rows. Both jae Boulenger 1903 and sylvaticus Loiselle and Welcomme 1971 have the lateral line greatly reduced or absent in contrast to the complete lateral line pore series in profundus.

\section{Comments}

Circumpenduncular scale row count provided complete separation of profundus and radiatus when counted at the point of least peduncle depth. Greenwood reported a modal count of 10 rows and two profundus with 12 rows, but apparently his counts were made slightly anterior to mine ( $P$. Greenwood, personal communication); the caudal peduncle tapers somewhat in profundus. Frequencies for 22 of the profundus types were as follows:
8 rows (3 fish including the holotype), 9(14), 10(3), 11(2). Circumference scale row counts are less diagnostic but almost half of the type specimens of profundus have more than 16 rows; this may be a useful supplementary character.

An important squamation character not mentioned in the original description of profundus is the extremely tall, narrow (columnar) lateral line scales. The ratio of height to length of exposed surface on a lateral line scale below the dorsal fin origin is a useful diagnostic character (Table 3). The palustris population was chosen to contrast with profundus because it is the most extreme in this character. Only one of 23 profundus fell within the range for palustris. The holotype of doggetti and a second specimen from Lake Victoria had an average ratio of 2.18 , the type of bangwelensis had 2.25, and three aurantiacus types averaged 2.44 .

The caudal fin of profundus seems to be more deeply forked than in radiatus but no attempt was made to quantify this character. Finally, color pattern may prove to be a useful character for separating specimens preserved in formalin. The only specimen of radiatus definitely known to come from Lake Victoria proper (UMMZ 194962) was preserved in formalin and closely resembles specimens from the Lower Luongo River (Fig. 2b). There are discrete longitudinal rows of dark brown spots which contrast noticeably with the diffuse color pattern of profundus (Fig. 2a).

\section{Speculation}

Rejection of the premise that there are two subspecies of radiatus invites a new explanation for the morphological variation that has caused so much confusion. Given the present lacunae of knowledge on the biology of African Barbus and on the physical environment where they live, an explanation is not yet possible. Yet, if an understanding of such variation can be useful for resolution of systematic problems with other species of Barbus, then an explanation should ultimately be sought and a working hypothesis might now be useful. It is hypothesized that the populational mosaic of morphology in radiatus reflects adaptive ecotypic responses to water temperature and current velocity. The hypothesis is not new as it has been evoked and tested numerous times for a variety of fishes, including cyprinids, but so far has not been 
suggested as applicable to Barbus. Supporting evidence for such responses in Barbus is indirect but certainly warrants consideration.

Longitudinal meristic counts and head proportions such as orbit diameter contribute to variation in radiatus. These characters have been shown in other fishes to respond to water temperature during some critical embryological stage. Some of the first observations of temperature effects on morphology and meristics of fish were made over fifty years ago (Jordan 1891; Hubbs 1922, 1926). The numerous studies made since then have been reviewed by Barlow (1961) and Fowler (1970). A generalization that has developed from prior studies is that populations in relatively colder water attain a larger size, have higher longitudinal meristic counts, and may also have relatively larger or smaller orbit than their warm-water conspecifics. A genetic component has sometimes been shown to be associated with what otherwise seems to be an environmental morphocline (Fowler 1970). However, laboratory studies have shown that the relationship of temperature to vertebral number is often a U-shaped function for a group of siblings with lowest vertebral number occurring at some intermediate temperature. Thus, minor genetic changes may lead to adaptation of a population to local conditions and year to year environmental fluctuations at a given locality may also contribute to meristic and morphometric variation.

Body depth, caudal peduncle length, and dorsal fin height also accounted for much of the variation between radiatus populations. It has been documented that fast-water populations of a given species tend to have a more attenuate body with slender caudal peduncle and relatively longer fins than their quiet-water conspecifics (Hubbs 1941, Smith 1966). Such morphological adaptations to fast-moving water are likely to be genetically determined but could also be influenced by factors such as temperature (i.e., through an increase in number of vertebrae).

By comparing published accounts for other fishes to observations on radiatus it can be inferred that aurantiacus-like morphs inhabit relatively cooler and perhaps also faster-flowing waters. Conversely, radiatus-like morphs may develop in warmer water and live in quieter water. Relative temperature stability (or climatic equability) of various habitats may also affect morphology (Smith \& Koehn 1971). Both laboratory and field studies are needed to test the above hypothesis and thereby, to determine the importance of ecotypic and genetic factors as contributors to geographic variation in radiatus.

The Upper Luongo and palustris populations represent the most extreme morphs of radiatus known (Fig. 4; Table 2). B. palustris was collected on a floodplain near sea level where the coast is warmed by the Moçambique Current, a southward deflection of the warm South Equatorial Current of the Indian Ocean (Jubb 1967). Both mean annual temperature and rainfall are relatively high near Beira.

In contrast, the Upper Luongo River is located on the central African plateau +1000 m above sea level and its radiatus population is isolated above Musonde Falls, an apparent barrier to upstream migration of several fish species. Thus confined, they may be obliged to reside in cooler, fasterflowing water than is usual for the species. There is a small reservoir on the Luongo just above Musonde Falls and this may warm the stream flow before it reaches radiatus in the Lower Luongo. Unfortunately there are no water temperature data for the Luongo River; I can only speculate.

Individuals of the Upper Luongo population (Fig. 2c) attain a larger size than those of any other population, have high longitudinal meristic counts, have attenuate body with caudal peduncle longer than can be accounted for by the presence of an extra vertebra, and have the first principal dorsal fin ray more strongly ossified than in any other population (i.e., movable segments only near the tip). A good case might be made for considering the Upper Luongo population to be a subspecies or perhaps even a distinct species as it seems to be isolated and a large majority of individuals can be discriminated from their nearest neighbors in the Lower Luongo.

It would be harder to make a case for specific recognition of the palustris population as it may routinely mix with adjacent coastal river populations via floodplains during exceptionally wet years (Farquharson 1962). These include the Lower Zambezi to the north with the type locality of $B$. radiatus and the Pongolo system with rubellus to the south (Fig. 3). Yet, as noted above, palustris deviates from the norm in an almost equal and opposite way from the Upper Luongo population. The morphology of palustris and high meristic counts of the Lake Nabugabu population (Table 2) argue against naming the Upper Luongo population at this time, especially since it is dis- 
tinguished entirely by characters known to be strongly influenced by environmental factors (Alizarin preparations of Upper and Lower Luongo specimens were compared; except for vertebral number, they agreed in every detail).

Tilapia baloni is also isolated in the Upper Luongo River and it differs morphologically from its allopatric sister species, $T$. sparrmanii, in many of the same ways that Upper Luongo radiatus are distinguished (Trewavas \& Stewart 1975). However, baloni has a distinctive color pattern and other characters which indicate that important genetic changes are involved. The possibility remains that Upper Luongo radiatus are equally different genetically. There is good evidence to indicate that Upper Luongo fishes have had a long history of isolation but the details are beyond the scope of this paper. The evidence includes unique morphology of various species populations living there as well as complete exclusion of several genera by Musonde Falls. Suffice it to say that further studies on Upper Luongo fishes will be worthwhile.

\section{Acknowledgements}

Special thanks go to Drs. Karl F. Lagler and Gerald R. Smith for encouragement, advice, and critical readings of the manuscript. The University of Michigan School of Natural Resources provided computer funds and the Museum of Zoology provided work space, $x$-ray facilities, and other supplies. This study was submitted as a thesis in partial fulfillment of requirements for the degree Master of Science in The University of Michigan, Ann Arbor, Michigan. The original data matrix was included therein as an appendix.

Much of the material upon which the study is based was collected while I was engaged as research assistant on a project jointly funded by the Department of Wildlife, Fisheries and National Parks, Ministry of Lands and Natural Resources, Zambia, and the Food and Agricultural Organization of the United Nations. The project was contracted to The University of Michigan under the supervision of Dr. K. F. Lagler. Dr. R. M. Bailey, consultant to the project, Mr. J. M. Kapetsky, research assistant, and others helped with various field efforts. Other valuable collections were made by Dr. E. K. Balon while he was employed by F.A.O. in Zambia; I thank him for many useful discussions and access to his field notes.
I am also greatly indebted to: Drs. P. H. Greenwood and K. E. Banister (BMNH) for critical readings of the paper and valuable discussions as well as work space, $\mathbf{x}$-rays, and access to collections under their care; Drs. E. J. Crossman and W. B. Scott (ROM), M. Poll and D. Thys van den Audenaerde (TM) for friendly cooperation and use of materials; Dr. R. A. Jubb and Mr. P. H. Skelton (AMPF) for a loan of specimens and reexamining the holotype of B. rubellus; Mr. F. Cichocki (UMMZ) for stimulating discussions and the program for confidence limits of ratios; Mr. and Mrs. R. Scully for their warm hospitability during my visit to Mwanza, Tanzania, and a subsequent small shipment of fishes; Mr. G. Howes and Ms. McLellan (BMNH), Ms. M. Parrington and Ms. E. Baker (UMMZ) for technical assistance. The principal components analysis was run using a program in the MIDAS routines of the Statistical Research Laboratory of the University of Michigan.

\section{References cited}

Bailey, R. G. 1969. The non-cichlid fishes of the eastward flowing rivers of Tanzania, East Africa. Rev. Zool. Bot. afr. 80: 170-199.

Banister, K. E. 1973. A revision of the large Barbus (Pisces, Cyprinidae) of East and Central Africa. Studies on African Cyprinidae Part II. Bull. Br. Mus. nat. Hist. (Zool.) 26: 1-148.

Barlow, G. W. 1961. Causes and significance of morphological variation in fishes. Syst. Zool. 10: 105-117.

Barnard, K. H. 1941. Note on alleged viviparity in Barbus viviparus and description of a new species of Beirabarbus. Ann. mag. nat. Hist. (8) 8: 469-471.

Bcll-Cross, G. 1965. Additions and amendments to the check list of the fishes of Zambia. The Puku 3: 29-43.

Bell-Cross, G. 1968. The distribution of fishes in Central Africa. Fish. Res. Bull. Zambia 4: 3-20.

Bell-Cross, G. 1972. The fish fauna of the Zambezi River system. Arnoldia (Rhodesia) 5: 1-19.

Boulenger, G. A. 1904. Diagnoses of three new species of Barbus from Lake Victoria. Ann. mag. nat. Hist. (7) 13: 449-450.

Boulenger, G. A. 1905. On a collection of fishes from Lake Bangweolo. Ann. mag. nat. Hist. (7) 16: 642-647.

Boulenger, G. A. 1910. On a large collection of fishes made by Dr. W. J. Ansorge in the Quanza and Bengo Rivers, Angola. Ann. mag. nat. Hist. (8) 6: 537-561.

Boulenger, G. A. 1911. Catalogue of the Fresh-water Fishes of Africa in the British Museum (Natural History). 2. London, 527 pp.

Crass, R. S. 1960. Notes on the freshwater fishes of Natal with descriptions of four new species. Ann. Natal Mus. 14: 405-458.

Farquharson, F. L. 1962. The distribution of cyprinids in South Africa. Ann. Cape prov. Mus. 2: 233-251.

Fowler, J. A. 1970. Control of vertebral number in teleostsan embryological problem. Quart. Rev. Biol. 45: 148-167. 
Goldstein, A. 1964. Biostatistics: An Introductory Text. The MacMillan Company, New York, 272 pp.

Greenwood, P. H. 1962. A revision of certain Barbus species (Pisces, Cyprinidae) from East, Central and South Africa. Bull. Br. Mus. nat. Hist. (Zool.) $8: 151-208$.

Greenwood, P. H. 1963. Notes on Barbus radiatus Peters 1853 and the subgenus Beirabarbus in East, South and Central Africa. Rev. Zool. Bot. afr. 67:20-28.

Greenwood, P. H. 1970. A revision of the cyprinid species Barbus (Enteromius) radiatus Peters, 1853, with a note on the synonymy of the subgenera Beirabarbus and Enteromius. Rev. Zool. Bot. afr. 82:1-13.

Herre, A. W. 1936. A new cyprinid genus and species and a new characin from Portuguese East Africa. Proc. Biol. Soc. Wash. 49:99-101.

Hopson, A. J. \& J. Hopson. 1965. Barbus (Pisces, Cyprinidae) of the Volta region. Bull. Br. Mus. nat. Hist. (Zool.) $13: 1-149$.

Hubbs, C. L. 1922. Variations in the number of vertebrae and other meristic characters of fishes correlated with the temperature of the water during development. Am. Nat. 56: $360-372$.

Hubbs, C. L. 1926. The structural consequences of modifications of the developmental rate in fishes considered in reference to certain problems of evolution. Am. Nat. 60:57-81.

Hubbs, C. L. 1941. The relation of hydrological conditions to speciation in fishes. pp. 182-195. In: A symposium on hydrobiology, Univ. Wis. Press, Madison, 416 pp.

Jordan, D. S. 1891. Relations of temperature to vertebrae among fishes. Proc. U.S. Nat. Museum 14:107-120.

Jubb, R. A. 1967. Freshwater Fishes of South Africa. A. A. Balkema, Cape Town, 248 pp.
Jubb, R. A. 1968. The Barbus and Varicorhinus species (Pisces, Cyprinidae) of Transvaal. Ann. Transv. Mus. 26:79-97.

Ladiges, W. 1964. Beiträge zur Zoogeographie und Oekologie der Süsswasserfische Angolas. Mitt. Hamburg. Zool. Mus. Inst. $61: 221-272$.

Morrison, D. F. 1967. Multivariate Statistical Methods. McGraw-hill, Inc., New York, 338 pp.

Peters, W. C. 1853. Eine nachträgliche Mittheilung über die Süsswasserfische von Mossambique. Ber. dt. Akad. Wiss. Berl. 1853: 783 .

Ricker, W. E. 1973. Linear regressions in fishery research. J. Fish. Res. Board Can. 30:409-434.

Smith, G. R. 1966. Distribution and evolution of the North American catostomid fishes of the subgenus Pantosteus, genus Catostomus. Misc. Publ. Mus. Zool., Univ. Michigan 129: $1-132$

Smith, G. R. 1973. Analysis of several hybrid cyprinid fishes from Western North America. Copeia 1973: 395-410.

Smith, G. R., \& R. K. Koehn. 1971. Phenetic and cladistic studies of biochemical and morphological characteristics of Catostomus. Syst. Zool. 20: 282-297.

Sokal, R. R., \& F. J. Rohlf. 1969. Biometry: the principles and practice of statistics in biological research. W. H. Freeman and Company, San Francisco, 776 pp.

Trewavas, E., \& D. J. Stewart. 1975. A new species of Tilapia (Pisces, Cichlidae) in the Zambian Zaïre system. Bull. Br. Mus. nat. Hist. (Zool.) 28: 191-197.

Present address:

Laboratory of Limnology,

University of Wisconsin,

Madison, Wisconsin 53706, USA 